\title{
Discrimination of Japanese isolates of Beauveria brongniartii (Deutero- mycotina: Hyphomycetes) by RFLP of the rDNA-ITS regions
}

\author{
Sanae Wada, ${ }^{1, *}$ Mitsuo Horita, ${ }^{2}$ Kazuyuki HirayaE ${ }^{3}$ and Mitsuaki Shimazu ${ }^{4}$ \\ ${ }^{1}$ National Institute of Agrobiological Sciences, Insect and Animal Sciences Division; Tsukuba, Ibaraki 305-8634, Japan \\ ${ }^{2}$ National Agricultural Research Center for Hokkaido Region; Sapporo, Hokkaido 062-8555, Japan \\ ${ }^{3}$ National Agricultural Research Center for Kyushu Okinawa Region; Nishigoshi, Kumamoto 861-1192, Japan \\ ${ }^{4}$ Forestry and Forest Product Research Institute; Tsukuba, Ibaraki 305-8687, Japan
}

(Received 17 March 2003; Accepted 19 July 2003)

\begin{abstract}
Isolates of the entomopathogenic fungus Beauveria brongniartii differ in the shape of the conidia and the amount of red pigment production, which are associated with the host insects they were obtained from. We investigated intraspecific polymorphisms among 38 isolates of $B$. brongniartii by using restriction fragment length polymorphisms (RFLP) of the internal transcribed spacer regions (ITS1 and ITS2), 5.8S rDNA, and small portions of the 18S and 28S rDNAs. Based on the RFLP patterns, the isolates were divided into two distinct groups. One group was composed mainly of isolates from longicorn beetles (Coleoptera: Cerambycidae), whereas the other group mainly contained isolates from scarab beetles (Coleoptera: Scarabaeidae). The DNA sequences of the amplified regions showed high homology between the groups, with only 7 substitutions in 852 nucleotides, and just 1 of the 7 substitutions accounted for the difference in the RFLP patterns between the two groups. Furthermore, RFLP successfully distinguished all of the $B$. brongniartii isolates from the 5 tested isolates of B. bassiana and the 1 of B. amorpha.
\end{abstract}

Key words: Beauveria brongniartii; RFLP; rDNA-ITS region; longicorn beetle; scarab beetle

\section{INTRODUCTION}

The fungus Beauveria brongniartii is mainly used to control a pest, Melolontha melolontha (Coleoptera: Scarabaeidae), inhabiting the soil in Europe, (Gillespie, 1988). In Japan, some strains of $B$. brongniartii isolated from the yellowspotted longicorn beetle, Psacothea hilaris (Coleoptera: Cerambycidae), have been used to control a mulberry and fig tree pest, P. hilaris, and the whitespotted longicorn beetle, a citrus tree pest, Anoplophora malasiaca. Use of the B. brongniartii strains in mulberry fields is allowed because of its low pathogenicity to the silkworm Bombyx mori (Kawakami, 1978). Some characteristics of $B$. brongniartii isolates differ depending on whether they were obtained from longicorn beetles or scarab beetles. For example, the shape of conidia of isolates from longicorn beetles are ovoid, whereas those from scarab beetles are long-ovoid (Kawakami, 1978; Samson et al., 1988). Isolates from scarab beetles generally produce red pigment in culture media, but those from longicorn beetles rarely produce pigment (Kawakami, 1978).

The internal transcribed spacer (ITS) regions of the nuclear ribosomal DNA (rDNA) repeat units evolve rapidly and may vary among species within a genus or among populations (White et al., 1990). Polymerase chain reaction (PCR) amplification has been used to detect polymorphisms in the ITS regions of fungi (Curran et al., 1994; Feibelman et al., 1994; Henrion et al., 1994; Matsumoto et al., 2000; Coats et al., 2002). Neuvéglise et al. (1994) showed restriction fragment length polymorphisms (RFLP) in the rDNA-ITS regions of isolates of $B$. brongniartii from different geographical and biological origins. DNA sequence data also confirmed the intraspecific genetic variability among the $B$. brongniartii strains.

In this study, we characterized 38 isolates of $B$. brongniartii from various insect hosts, including longicorn beetles and scarab beetles, together with 5 isolates of $B$. bassiana and 1 isolate of $B$. amor$p h a$, on the basis of PCR-RFLP analysis.

\footnotetext{
* To whom correspondence should be addressed at: E-mail: sunny@affrc.go.jp
} 


\section{MATERIALS AND METHODS}

Fungal isolates and culture conditions. The Beauveria isolates used in this study were from the collection maintained at the National Institute of
Agrobiological Sciences and Forestry and Forest Products Research Institute, both in Tsukuba, Ibaraki, Japan. Most of the isolates were collected in Japan, covering the mainland from Hokkaido to Kyushu districts. One isolate was from China

Table 1. List of Beauveria spp. isolates studied

\begin{tabular}{|c|c|c|c|c|c|}
\hline Species & Isolate $^{a}$ & Source of isolate & Family of host ${ }^{b}$ & Geographical origin & Year of isolation \\
\hline \multirow[t]{38}{*}{ B. brongniartii } & 614 & Psacothea hilaris & $\mathrm{C}$ & Gifu & 1976 \\
\hline & 677 & Psacothea hilaris & $\mathrm{C}$ & Gifu & 1977 \\
\hline & 678 & Psacothea hilaris & $\mathrm{C}$ & Gifu & 1977 \\
\hline & 769 & Psacothea hilaris & $\mathrm{C}$ & Yamanashi & 1978 \\
\hline & 782 & Psacothea hilaris & $\mathrm{C}$ & Gunma & 1978 \\
\hline & $793 \mathrm{~L}$ & Psacothea hilaris & $\mathrm{C}$ & Kanagawa & 1978 \\
\hline & 853 & Psacothea hilaris & $\mathrm{C}$ & Nagano & 1980 \\
\hline & 854 & Psacothea hilaris & $\mathrm{C}$ & Nagano & 1980 \\
\hline & 858 & Psacothea hilaris & $\mathrm{C}$ & Nagano & 1980 \\
\hline & 864 & Psacothea hilaris & $\mathrm{C}$ & Nagano & 1980 \\
\hline & 867 & Psacothea hilaris & $\mathrm{C}$ & Ibaraki & 1980 \\
\hline & 876 & Psacothea hilaris & $\mathrm{C}$ & Gunma & 1980 \\
\hline & 900 & Psacothea hilaris & $\mathrm{C}$ & Tottori & 1981 \\
\hline & 914 & Psacothea hilaris & $\mathrm{C}$ & Yamanashi & 1982 \\
\hline & 1002 & Psacothea hilaris & $\mathrm{C}$ & Kumamoto & 1986 \\
\hline & B921 & Psacothea hilaris & $\mathrm{C}$ & Ibaraki & 1992 \\
\hline & 672 & Cerambycidae & $\mathrm{C}$ & Kanagawa & 1977 \\
\hline & 676 & Apriona japonica & $\mathrm{C}$ & Gunma & 1977 \\
\hline & 860 & Apriona japonica & $\mathrm{C}$ & Ibaraki & 1980 \\
\hline & 774 & Soil & - & Kanagawa & 1978 \\
\hline & 995 & Pterolophia annulata & $\mathrm{C}$ & Kumamoto & 1986 \\
\hline & 1024 & Anoplophora malasiaca & $\mathrm{C}$ & Nagasaki & 1987 \\
\hline & B931 & Mesosa longipennis & $\mathrm{C}$ & Ibaraki & 1993 \\
\hline & ※F237 & Moechotypa diphysis & $\mathrm{C}$ & Nagasaki & 1978 \\
\hline & $\circledast_{\mathrm{F} 402}$ & Mesosa longipennis & $\mathrm{C}$ & Unknown, Japan & Unknown \\
\hline & $※ \overline{\mathrm{F} 666}$ & Uraecha bimaculata & $\mathrm{C}$ & Miyagi & 1988 \\
\hline & ※F1118 & Holotrichia parallela & $\mathrm{S}$ & Cangzhou, China & 1994 \\
\hline & ※F77 & Mimela costata & $\mathrm{S}$ & Nagano & 1976 \\
\hline & ※F614 & Soil & - & Ibaraki & Unknown \\
\hline & $※_{F 621}$ & Anomala cuprea & $\mathrm{S}$ & Iwate & 1987 \\
\hline & ※F638-1 & Anomala cuprea & $\mathrm{S}$ & Unknown, Japan & 1988 \\
\hline & ※638-2 & Anomala cuprea & $\mathrm{S}$ & Unknown, Japan & 1988 \\
\hline & ※F876-1 & Mimela testaceipes & $\mathrm{S}$ & Hokkaido & 1990 \\
\hline & ※F876-2 & Mimela testaceipes & $\mathrm{S}$ & Hokkaido & 1990 \\
\hline & ※F1003-1 & Mimela testaceipes & $\mathrm{S}$ & Yamagata & Unknown \\
\hline & $\varkappa_{F 1003-2}$ & Mimela testaceipes & $\mathrm{S}$ & Yamagata & Unknown \\
\hline & ※F1120 & Popillia japonica & $\mathrm{S}$ & Hokkaido & 1994 \\
\hline & ※F389 & Unknown & - & Nagasaki & 1978 \\
\hline \multirow[t]{5}{*}{ B. bassiana } & 32 & Bombyx mori & $\mathrm{B}$ & Kanagawa & 1960 \\
\hline & ※F263 & Monochamus altenatus & $\mathrm{C}$ & Unknown, Japan & Unknown \\
\hline & $\circledast_{\text {F760 }}$ & Bombyx mori & $\mathrm{B}$ & Unknown, Japan & Unknown \\
\hline & 1018 & Psacothea hilaris & $\mathrm{C}$ & Gunma & 1987 \\
\hline & 1022 & Episomus mundus & $\mathrm{Cu}$ & Kagoshima & 1988 \\
\hline B. amorpha & ※F953 & Scarabaeidae & $\mathrm{S}$ & Tokyo & 1991 \\
\hline
\end{tabular}

${ }^{a}$ Isolates prefixed “※F” indicate those maintained at the Forestry and Forest Products Research Institute (Tsukuba, Ibaraki, Japan). Underlined isolates were used in nucleotide sequence studies.

${ }^{\mathrm{b}} \mathrm{C}$, Cerambycidae; S, Scarabaeidae; B, Bombycidae; $\mathrm{Cu}$, Curculionidae. 
(Table 1). The conidia of each isolate were cultured in SMY medium (4\% maltose, $1 \%$ peptone, and $1 \%$ yeast extract) on a shaker $(120 \mathrm{rpm})$ at $25^{\circ} \mathrm{C}$ for 3 to 5 days.

DNA extraction. The cultured mycelia were harvested, washed with distilled water by filtration, and freeze-dried. Approximately $1 \mathrm{~g}$ of dried sample was ground in liquid nitrogen and then resuspended in $16 \mathrm{ml}$ of buffer $(100 \mathrm{~mm}$ citric acid, $100 \mathrm{~mm}$ phosphoric acid [pH 6.0], and $100 \mathrm{~mm}$ EDTA). Then $2 \mathrm{ml}$ of $10 \%$ SDS was added, the mixture was placed on ice for $15 \mathrm{~min}, 4.5 \mathrm{ml} 5 \mathrm{M}$ $\mathrm{NaCl}$ was added, and the mixture was stored overnight at $4^{\circ} \mathrm{C}$. After centrifugation at $10,000 \times g$ for $40 \mathrm{~min}$, the supernatant was transferred to a fresh tube, and a 0.6-volume of isopropanol was added to precipitate the DNA. The sample was centrifuged at $10,000 \times g$ for $10 \mathrm{~min}$, and the pellet was washed with $70 \%$ ethanol, dried, and resuspended in $5 \mathrm{ml}$ TE-sarcosinate buffer $(20 \mathrm{mM}$ Tris $\mathrm{HCl}$ [pH 8.0], $0.25 \mathrm{~mm}$ EDTA, and $0.4 \%$ sodium $\mathrm{N}$-laurolyl sarcosinate). Then $5 \mathrm{~g} \mathrm{CsCl}$ and $285 \mu \mathrm{l}$ ethidium bromide $(10 \mathrm{mg} / \mathrm{ml})$ were added, and the sample was centrifuged at $300,000 \times g$ for $18 \mathrm{~h}$. The DNA band was recovered and, after several washes with n-butanol, 3 volumes of TE buffer were added. The DNA was precipitated with 2 volumes of ethanol and was recovered by centrifugation at $5,500 \times g$ for $10 \mathrm{~min}$. The pellet was washed, dried, and resuspended in TE buffer.

PCR amplification. The region of the ribosomal repeat, including a small portion of $18 \mathrm{~S}$ rDNA, ITS 1, 5.8S rDNA, ITS2, and a small portion of the $28 \mathrm{~S}$ rDNA, was amplified by PCR. The primers used, PN3: 5'-CCGTTGGTGAACCAGCGGAGGGATC-3' and PN16: 5'-TCCCTTTCAACAATTTCACG-3', were described by Neuvéglise et al. (1994). PCR reactions were carried out in a $100-\mu 1$ volume containing $200 \mu \mathrm{M}$ of each dNTP, $100 \mathrm{pmol}$ of each primer, 2.5 U Taq DNA polymerase (Takara Biomedicals, Japan), and $0.1 \mu \mathrm{g}$ of DNA template. Cycling parameters consisted of an initial denaturation at $95^{\circ} \mathrm{C}$ for $3 \mathrm{~min}$, followed by 25 cycles of denaturation at $94^{\circ} \mathrm{C}$ for $1 \mathrm{~min}$, annealing at $55^{\circ} \mathrm{C}$ for $2 \mathrm{~min}$, and extension at $72^{\circ} \mathrm{C}$ for $3 \mathrm{~min}$, by using a thermal cycler (PC800, Astec, Japan).

RFLP analysis. The amplified DNA was digested with the 4-base recognition restriction enzymes AluI, HaeIII, MspI, HhaI (Toyobo Biochemicals, Japan), MboI, and AccII (Takara) according to the manufacturer's instructions. Digested fragments were separated on 3\% agarose (NuSieve 3:1 agarose, FMC BioProducts, Maryland, USA) by gel electrophoresis in $0.5 \times \mathrm{TBE}$ buffer at $50 \mathrm{~V}$, stained with ethidium bromide, and photographed under UV light. A 100-bp DNA ladder (Takara) was used as size markers.

DNA sequencing. The sequences of the ITS regions of 4 isolates-F402 and F638-1 (B. brongniartii), F760 (B. bassiana), and F953 (B. amorpha)—were analyzed. To increase the cloning efficiency of the blunt-ended DNA, fragments polished by using a PCR Polishing Kit (Stratagene, California, USA) were cloned into pCR-Script ${ }^{\mathrm{TM}}$ $\mathrm{SK}(+)$ (Stratagene). The cloned plasmid DNA was extracted by using the alkali-SDS lysis method. Sequencing reactions were carried out by dideoxy chain termination using an AutoRead ${ }^{\mathrm{TM}}$ Sequencing Kit (Amersham Pharmacia, Buckinghamshire, UK) with primers PN16, PN12 (5'-CAATGTGCGTTCAAAGATTCGAT-3'), and PN10 (5'-TCCGCTTATTGATATGCTTAAG-3'), as described by Neuvéglise et al. (1994). Sequence information was obtained by using an ALF DNA Sequencer II (Amersham Pharmacia). Sequences of the 4 isolates were manually aligned for comparison.

\section{RESULTS}

\section{Separation of species and isolates}

Amplification of the ITS regions including the 5.8S rDNA from all isolates of $B$. brongniartii, $B$. bassiana, and $B$. amorpha resulted in approximately 950-bp products. Polymorphisms among the amplified DNAs were detected by digestion with AluI, HaeIII, MspI, HhaI, and AccII (Table 2); no variations were observed in the restriction pattern with $M b o \mathrm{I}$. The restriction patterns with AluI, HaeIII, and HhaI discriminated all isolates of $B$. bassiana from all isolates of $B$. brongniartii and $B$. amorpha. Similarly, the $B$. amorpha isolate was discriminated from all isolates of the other Beauveria species by the restriction patterns obtained with $M s p I$. The restriction patterns from AccII discriminated all isolates of Beauveria species from each other (Fig. 1) and grouped most isolates of $B$. brongniartii into isolates from longicorn beetles and those from scarab beetles (Table 3). According to the RFLP patterns, F1118 (isolated from scarab beetle in China) was categorized with isolates from 


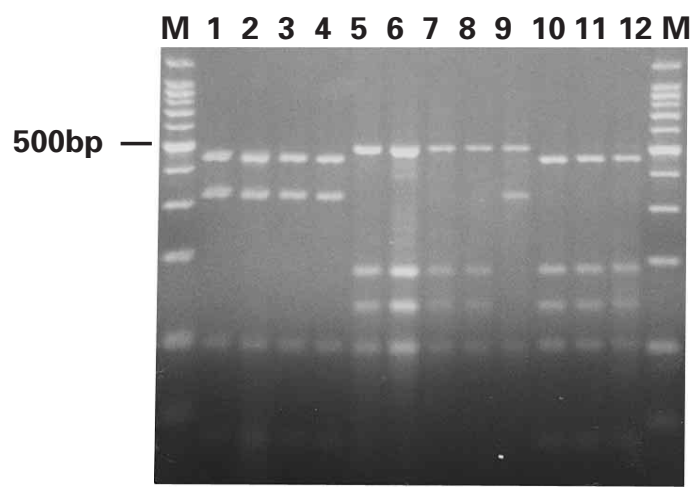

Fig. 1. Restriction patterns of rDNA-ITS regions of $B$. brongniartii, B. bassiana, and B. amorpha digested with AccII. Lanes 1-4, B. brongniartii isolated from Scarabaeidae (1: F77, 2: F876-1, 3: F638-1, 4: F1120); 5-8, B. brongniartii isolated from Cerambycidae (5: 867, 6: 1024, 7: F237, 8: F666); 9, $B$. amorpha (F953) and 10-12, B. bassiana (10: F263, 11: 32, 12: F760). Lane $M$ are 100 bp-ladder DNA size markers. longicorn beetle, and 774 and F614, which were obtained from soil, belonged to distinct RFLP pattern groups of $B$. brongniartii.

\section{Sequence of rDNA-ITS region}

We then sequenced the rDNA-ITS regions (about 880 nucleotides) of the 4 isolates of Beauveria spp. that are distinguishable from each other by RFLP analysis. (Fig. 2). Each nucleotide sequence dataset for F402, F638-1, F760, and F953 was deposited in the DNA Databank of Japan under the accession numbers AB100036, $\mathrm{AB} 100037$, $\mathrm{AB} 100038$, and $\mathrm{AB} 100039$, respectively. All isolates revealed similar sequences, and the differences were concentrated within ITS regions. The difference between $B$. brongniartii F402 (isolated from M. longipennis) and F638-1 (isolated from A. cuprea) was 7 of the $852 \mathrm{nu}-$

Table 2. Sizes (bp) of DNA fragments obtained after endonuclease digestion of the ITS regions of rDNA from Beauveria spp. isolates

\begin{tabular}{|c|c|c|c|c|c|c|}
\hline \multirow{2}{*}{$\begin{array}{l}\text { Restriction } \\
\text { pattern no. }\end{array}$} & \multicolumn{6}{|c|}{ Sizes of fragments with each enzyme } \\
\hline & MboI & AluI & HhaI & MspI & HaeIII & $A c c \mathrm{Il}$ \\
\hline \multirow[t]{8}{*}{1} & 660 & 630 & 545 & 465 & 280 & 520 \\
\hline & 190 & 145 & 320 & 265 & 200 & 185 \\
\hline & 60 & 100 & 75 & 95 & 155 & 145 \\
\hline & & 65 & & 60 & 120 & 105 \\
\hline & & & & 25 & 90 & \\
\hline & & & & 15 & 55 & \\
\hline & & & & & 20 & \\
\hline & & & & & 10 & \\
\hline \multirow[t]{7}{*}{2} & & 470 & 405 & 290 & 290 & 480 \\
\hline & & 160 & 320 & 265 & 200 & 330 \\
\hline & & 145 & 140 & 175 & 155 & 105 \\
\hline & & 100 & 75 & 95 & 120 & 45 \\
\hline & & 65 & & 60 & 90 & \\
\hline & & & & 25 & 55 & \\
\hline & & & & 15 & 20 & \\
\hline \multirow[t]{8}{*}{3} & & & & & 280 & 480 \\
\hline & & & & & 190 & 185 \\
\hline & & & & & 165 & 145 \\
\hline & & & & & 120 & 105 \\
\hline & & & & & 90 & 45 \\
\hline & & & & & 55 & \\
\hline & & & & & 20 & \\
\hline & & & & & 10 & \\
\hline \multirow[t]{3}{*}{4} & & & & & & 520 \\
\hline & & & & & & 330 \\
\hline & & & & & & 105 \\
\hline
\end{tabular}


Table 3. Restriction pattern groups of Beauveria spp. isolates

\begin{tabular}{|c|c|c|c|c|c|c|c|}
\hline \multirow{2}{*}{$\begin{array}{l}\text { Restriction } \\
\text { pattern } \\
\text { groups }\end{array}$} & \multicolumn{6}{|c|}{ Restriction patterns with each enzyme ${ }^{a}$} & \multirow{2}{*}{ Isolates of the same restriction pattern group } \\
\hline & MboI & AluI & HhaI & MspI & HaeIII & AccII & \\
\hline Group A & 1 & 1 & 1 & 1 & 1 & 1 & $\begin{array}{l}\text { B. brongniartii from Cerambycidae: } 614,677,678,769 \text {, } \\
782,793 \mathrm{~L}, 853,854,858,864,867,876,900,914,1002 \text {, } \\
\text { B921, 672, 676, 860, 995, 1024, B931, F237, F402, and } \\
\text { F6 } 66 \\
\text { B. brongniartii from Scarabaeidae: F1118 } \\
\text { B. brongniartii from soil: } 774\end{array}$ \\
\hline Group B & 1 & 1 & 1 & 1 & 2 & 2 & $\begin{array}{l}\text { B. brongniartii from Scarabaeidae: F77, F621, F638-1, } \\
\text { F638-2, F876-1, F876-2, F1003-1, F1003-2, F1120, and } \\
\text { F389 } \\
\text { B. brongniartii from soil: F614 }\end{array}$ \\
\hline Group C & 1 & 2 & 2 & 1 & 3 & 3 & B. bassiana: $32, \mathrm{~F} 263, \mathrm{~F} 760,1018$, and 1022 \\
\hline Group D & 1 & 1 & 1 & 2 & 1 & 4 & B. amorpha: F953 \\
\hline
\end{tabular}

${ }^{\text {a }}$ No. of the restriction pattern type refers to that in Table 2.

cleotides sequenced $(0.82 \%)$. A single base substitution (the 223rd base from the beginning of the sequences in Fig. 2), which changes a recognition site of AccII, was responsible for the discrimination between the longicorn beetle isolates and the scarab beetle isolates.

\section{DISCUSSION}

We used RFLP analysis to reveal variations among rDNA amplified fragments of $B$. brongniartii. The patterns of the 38 isolates investigated allocated them into 2 groups correlated with their host insects: one group comprised isolates from the Cerambycidae, and the other, those from the Scarabaeidae. Nucleotide differences between the 2 groups accounted for only $0.82 \%$ of the region sequenced, and a single base change was responsible for the RFLP grouping. The identities of the resulting RFLP bands are unknown, so their suitability for determining the relationship among isolates is generally only assumed (Maurer et al., 1997). Thus far, many fungi have been analyzed by using RFLP of the ITS region of the rDNA, because this method is simple and useful for examining intraspecific polymorphisms and for distinguishing morphologically similar species (Matsumoto et al., 2000). For example, Neuvéglise et al. (1994) investigated 28 B. brongniartii strains isolated from coleopterans and lepidopterans collected mainly from Europe and Madagascar, and divided the fungi into 6 RFLP-associated groups. All isolates from the white grub Hoplochelus marginalis (Coleoptera) were in Group 1, which also contained 1 isolate from another source. Differences in the target DNA sequence between group 1 and the other groups ranged from $2.6 \%$ to $9.1 \%$-all exceeding the value we obtained. In the study, geographical origins of fungal isolates were not correlated with the RFLP groups. We similarly observed no polymorphisms associated with geographical origins of the Japanese isolates. The isolate list of Neuvéglise et al. (1994) contained 2 Japanese strains isolated from Mimela costata (Coleoptera: Scarabaeidae) and Pissodes nitidus (Coleoptera: Curculionidae). These strains were assigned to RFLP group 2, which consisted of strains from scarab beetles and weevils (Coleoptera: Curculoinidae) mainly from Europe. When we compared the sequences of the rDNA-amplified fragments of the isolate $\mathrm{Bt} 33$ belonging to group 2 with that of our isolate F638-1 from scarab beetle, 17 of the 805 nucleotides differed $(2.1 \%)$; this value is higher than the difference between our 2 RFLP groups. Furthermore, the assumed band pattern of group 2 isolates digested with AccII was different from that of our scarab beetle group. In our study, F1118 from scarab beetles in China showed atypical RFLP patterns, but it is unclear whether this exception was due to the geographical origin of the isolate. Further investigation with more isolates from Japan and neighboring countries is needed to 
B. brongniartii F402 attaccgagt tttcaactcc ctaaccctta tgtgasccta cctattgttg cttcggcgga ctcgccccag *ccggacgcg

B. brongniartii

B. brongniartii

B. amorpha

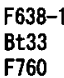

$\cdots \cdots \cdots \cdots \cdots$
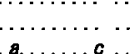

....................

F953

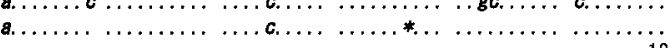

F402 gac tggac cagcggccgc cgggggccct taaactcttg tattatcagc accttctgaa tacgcegcaa ggcвaracas acasatcaaa actttcaaca

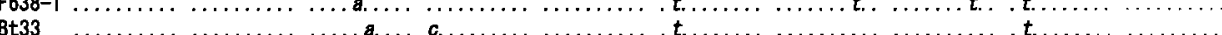

Bt3s

$\mathrm{F} 760$
$\mathrm{~F} 953$ .

F402 280

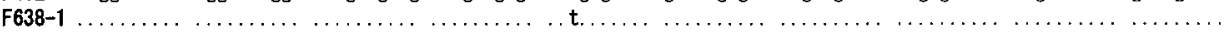

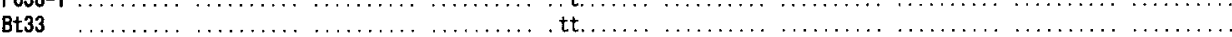

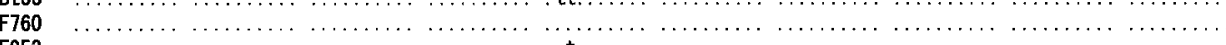

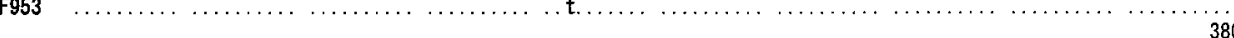

F402 tgcgccegcc agcattctgg cgggcatgcc tgttcgagcg tcatttcaac cctcgacct* cotttgggga agtcggcgtt ggggaccggc agcacaccgc

F638-1

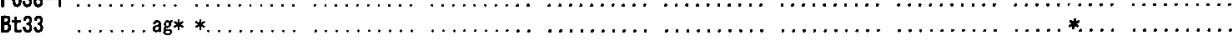

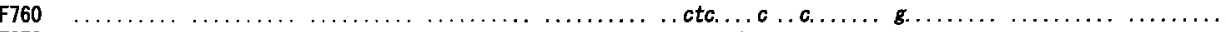

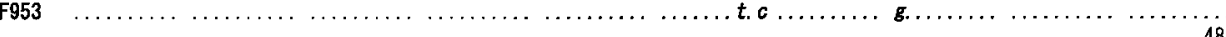

F402 cggccetgas atggagtggc ggccegtccg cggcgacctc tgcgtagtaa tccaactcgc accggaaccc cgacgtggcc *acgccstaa aacacccaac

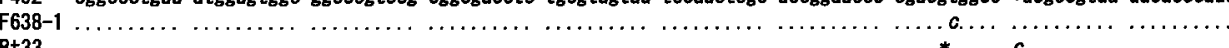

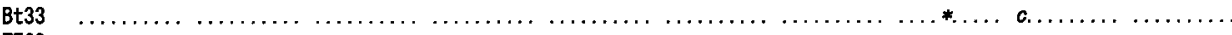

F760

..c.... a..g.

$\ldots \ldots \ldots \ldots . . . . .$.

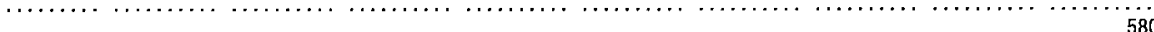

ttctgaacgt tgacctcgaa tcaggtagga ctacccgctg aacttaagca tatcaataag cggaggaaaa gaaaccaaca gggattgccc cagtaacggc

F638-1

Bt33

F760

.

680

F638-

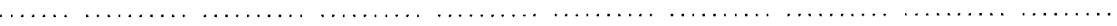

Bt33

F760

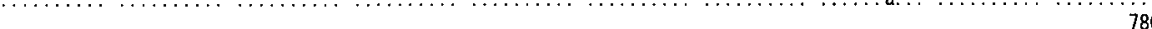

780

aacgggacgc cacagagggt gagagccccg tatggtcgga caccgagcct ctgtaaagct ccttcgacga gtcgagtagt ttgggaatgo tgctcaaaa

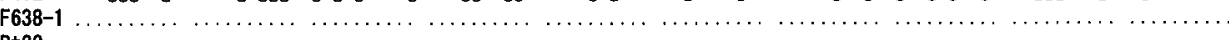

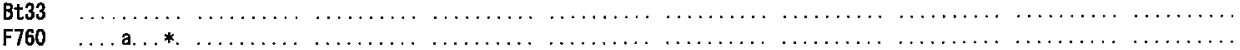

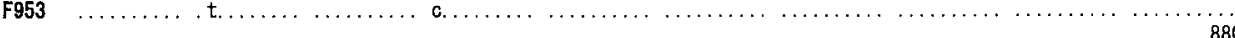

F402 gggaggtata tgtcttctaa agctaaatat tggccagaga ccgatagcgc acaagtagag tgatcgaaag atgaaaagca ctttgaaaag agagttaaaa

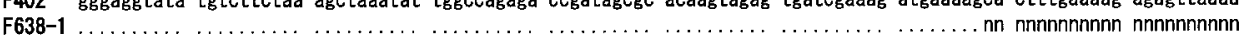

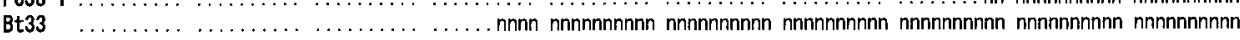

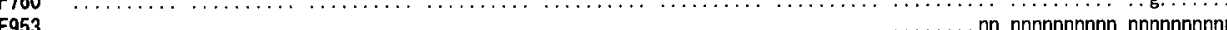

Fig. 2. Sequence alignments of ITS regions, 5.8S rDNA, and the 5' end of the 28S rDNA of Beauveria spp. isolates: F402, $B$. brongniartii isolated from $M$. longipennis; F638-1, B. brongniartii isolated from A. cuprea; Bt33, B. brongniartii isolated from Melolontha melolontha (Coleoptera: Scarabaeidae) in France (Neuvéglise et al., 1994); F760, B. bassiana isolated from B. mori; F953, B. amorpha isolated from a scarab beetle. Only the nucleotides differing from those of sequences of F402 are shown. Identities, deletions, and undetermined nucleotides are noted by dots, stars and n, respectively. Nucleotides of ITS1 and ITS2 are shown in italics.

analyze the genetic divergence of $B$. brongniartii with regard to geographical origin.

In general, fungal isolates are more virulent to the original host than to other hosts (Tanada and Kaya, 1993). In a bioassay, $1.8 \times 10^{4}$ conidia $/ \mathrm{ml}$ of the 782 isolate from $P$. hilaris (longicorn beetle) killed all $P$. hilaris tested, whereas $1.4 \times 10^{8}$ coni$\mathrm{dia} / \mathrm{ml}$ of F1120 from Popillia japonica (scarab beetle) did not kill $P$. hilaris (data not shown). If the RFLP patterns reflecting the host insect taxa can serve as an index of the virulence of the isolates, this information will be useful in selecting isolates for effective pest control.

In addition to the differentiation of isolates within B. brongniartii, our RFLP analysis clearly differentiated $B$. bassiana, B. amorpha, and $B$. brongniartii, which are morphologically similar species. Several attempts have been made to differentiate strains of B. bassiana (St. Leger et al., 1992; Hegedus and Khachatourians, 1996). Coats et al. (2002) identified polymorphism in the rDNA and ITS regions of $B$. bassiana isolates by using PCR-RFLP and DNA sequencing, but found no noteworthy correlation between the RFLP and host 
range. Likewise, we could not detect RFLP in similar DNA regions of $B$. bassiana investigated by Coats et al. (2002) despite the different original hosts. Using RFLP and random amplified polymorphic DNA (RAPD) techniques on total genomic DNA, Maurer et al. (1997) showed clear relationships between the genotype of B. bassiana and various defined host species. Therefore, analysis of total genomic DNA can be useful when examining the polymorphism of $B$. brongniartii isolates, for example in relation to geographical origins. Although $B$. brongniartii is important as a pest control agent, knowledge of its geographical distribution, pathogenecity, genetic diversity, and other attributes is more limited than for those of $B$. bassiana, especially for isolates from Asian countries. For the development of microbial control by $B$. brongniartii, it is indispensable to monitor the released strain and distinguish it from the other isolates in target insects, nontarget insects, and the environment. Therefore, additional genetic experiments are necessary to identify individual isolates of $B$. brongniartii.

\section{ACKNOWLEDGEMENTS}

We are grateful to Dr. M. R. Goldsmith for her critical reading of this manuscript. We also thank Dr. H. Tamura for his advice.

\section{REFERENCES}

Coats, B. S., R. L. Hellmich and L. C. Lewis (2002) Beauveria bassiana haplotype determination based on nuclear rDNA internal transcribed spacer PCR-RFLP. Mycol. Res. 106: 40-50.

Curran, J., F. Driver, J. W. O. Ballard and R. J. Milner (1994) Phylogeny of Metarhizium: analysis of ribosomal DNA sequence data. Mycol. Res. 98: 547-552.

Feibelman, T., P. Bayman and W. G. Cibula (1994) Length variation in the internal transcribed spacer of ribosomal DNA in chanterelles. Mycol. Res. 98: 614-618.
Gillespie, A. T. (1988) Use of fungi to control pests of agricultural importance. In Fungi in Biological Control Systems (M. N. Burge ed.). Manchester University Press, Manchester, pp. 37-60.

Hegedus, D. D. and G. G. Khachatourians (1996) Identification and differentiation of the entomopathogenic fungus Beauveria bassiana using polymerase chain reaction and single-strand comformation polymorphism analysis. $J$. Invertebr. Pathol. 67: 289-299.

Henrion, B., G. Chevalier and F. Martin (1994) Typing truffle species by PCR amplification of the ribosomal DNA spacers. Mycol. Res. 98: 37-43.

Kawakami, K. (1978) On an entomogenous fungus Beauveria tenella (Delacroix) Siemaszko isolated from the yellow-spotted longicorn beetle, Psacothea hilaris PASCOE. Bull. Seric. Exp. Stn. (Tokyo) 27: 445-467 (in Japanese with English summary).

Matsumoto, C., K. Kageyama, H. Suga and M. Hyakumachi (2000) Intraspecific DNA polymorphism of Pythium irregulare. Mycol. Res. 104: 1333-1341.

Maurer, P., Y. Couteaudier, P. A. Girard, P. D. Bridge and G. Riba (1997) Genetic diversity of Beauveria bassiana and relatedness to host insect range. Mycol. Res. 101: 159-164.

Neuvéglise, C., Y. Brygoo, B. Vercambre and G. Riba (1994) Comparative analysis of molecular and biological characteristics of strains of Beauveria brongniartii isolated from insects. Mycol. Res. 98: 322-328.

Samson, R. A., H. C. Evans and J-P. Latgé (1988) Plate 65. In Atlas of Entomopathogenic Fungi (R. A. Samson, H. C. Evans and J-P. Latgé eds.). Springer-Verlag, Berlin, p. 83.

St. Leger, R. J., L. L. Allee, B. May, R. C. Staples and D. W. Roberts (1992) World-wide distribution of genetic variation among isolates of Beauveria spp. Mycol. Res. 96: 1007-1015.

Tanada, Y. and H. K. Kaya (1993) Fungal infection. In Insect Pathology (Y. Tanada and H. K. Kaya eds.). Academic Press, San Diego, pp. 318-387.

White, T. J., T. Bruns, S. Lee and J. Taylor (1990) Amplification and direct sequencing of fungal ribosomal RNA genes for phylogenetics. In PCR Protocols, a Guide to Methods and Applications (M. A. Innis, D. H. Gelfand, J. J. Sninsky and T. J. White eds.). Academic Press, San Diego, pp. 315-322. 